(2) Open Access Full Text Article

\title{
Spontaneous development of macular ischemia in a case of racemose hemangioma
}

This article was published in the following Dove Press journal:

Clinical Ophthalmology

7 July 2011

Number of times this article has been viewed

\section{Dimitrios Panagiotidis \\ Dimitrios Karagiannis \\ loannis Tsoumpris}

Second Ophthalmology Department of Athens University, Attikon Hospital, Athens, Greece
Correspondence: Dimitrios A Karagiannis Second Ophthalmology Department of Athens University, Attikon Hospital Elefterotrias 49B str, Kifissia I4562, Athens, Greece

Tel +30694 5973800

$\mathrm{Fax}+302108828471$

Email dimitrioskaragiannis@doctors.org.uk
Purpose: To report a rare case of racemose hemangioma which developed spontaneous macular ischemia.

Methods: A 32-year-old healthy Caucasian lady presented complaining of recent deterioration of vision in her left eye. At presentation, her best corrected visual acuity (BCVA) was 20/20 in her right eye and counting fingers in her left eye (LE). Fundus examination and fluorescein angiography were performed. The patient had regular follow-up appointments over a period of 8 years.

Results: Fundus examination and fluorescein angiography revealed findings consistent with arteriovenous communications of the retina or racemose hemangioma, in the posterior pole of the LE with the presence of macular ischemia. Complete and systemic examination was unremarkable, excluding the possibility of Wyburn-Mason syndrome. Eight years after presentation, findings and BCVA in the LE have remained stable, with no extension of the retinal ischemia or development of neovascularization.

Conclusion: Although extensive retinal ischemia has been reported to result in complications such as retinal or iris neovascularization, in our case the macular ischemia has not expanded further over a period of 8 years. However, due to this macular ischemia the patient unfortunately lost her central vision.

Keywords: racemose hemangioma, macular ischemia, retinal ischemia

\section{Introduction}

Racemose hemangioma is rare. The development of extensive retinal ischemia including macular ischemia resulting in rubeosis has been reported. We describe a case of racemose hemangioma which spontaneously developed macular ischemia alone, resulting in poor visual acuity. This finding has remained stable over a follow-up period of 8 years with no further complication.

\section{Case report}

A 32-year-old healthy Caucasian lady presented complaining of recent deterioration of vision in her left eye (LE). At presentation, her best corrected visual acuity (BCVA) was 20/20 in her right eye and counting fingers in her LE. The anterior segment and intraocular pressures were normal in both eyes. Fundus examination and fluorescein angiography revealed findings consistent with arteriovenous communications of the retina or racemose hemangioma, in the posterior pole of the LE with the presence of macular ischemia (Figures 1 and 2). There were no other signs of peripheral ischemia. Complete and systemic examination including MRI scan was unremarkable, 


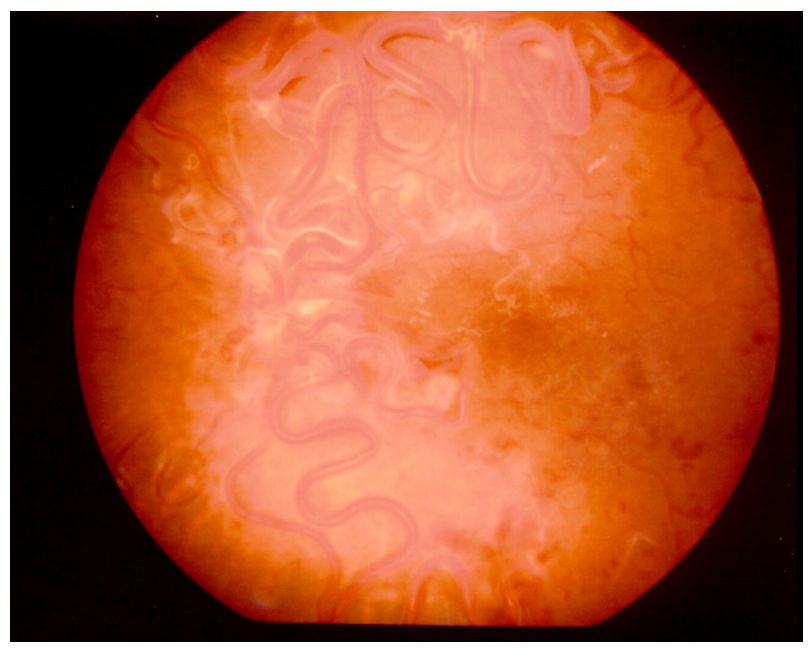

Figure I Color fundus picture of the left eye at presentation showing the retinal racemose angioma. The optic disc is obscured by vessels. The retinal vessels in the macular area are white indicating ischemia. Findings remained stable over the 8 year follow-up period.

excluding the possibility of Wyburn-Mason syndrome with arteriovenous malformations of the optic nerve and midbrain. There was no family history of note. Eight years after initial presentation, findings and BCVA in the LE have remained stable, with no extension of the retinal ischemia or development of neovascularization.

\section{Comment}

Congenital unilateral arteriovenous malformations of the retinal vasculature are rare. The lesions have been reported either to remain static or regress ${ }^{1-2}$ or to enlarge gradually.

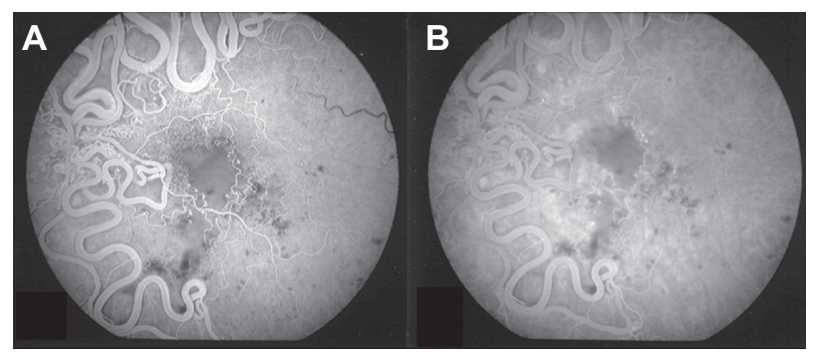

Figure 2 Early (A) and late (B) phases of fundus fluorescein angiography of the left eye showing macular ischemia and extensive arteriovenous communications and dilated intertwined vessels. There are small hemorrhages and exudates and white (sheathed) vessels in the macular area.
Vision may be affected directly due to macular involvement or by producing hemorrhage or exudation. ${ }^{3,4}$ Based on Archer et al the angioma in our case was grade 3, although there were no systemic findings. ${ }^{5}$ We present a case of racemose hemangioma which spontaneously developed macular ischemia. Although extensive retinal ischemia has been reported to result in complications such as retinal or iris neovascularization, ${ }^{1}$ in our case the macular ischemia has not expanded further over a period of 8 years. However, due to this macular ischemia the patient unfortunately lost her central vision. The etiology of the ischemia is unclear. It has been postulated that either an enlarged malformation using part of the blood supply of the retina may cause ischemia, or there was a partial thrombosis which caused circulatory stasis within the lesion. 6,7

\section{Disclosure}

The authors report no conflict of interest in this work.

\section{References}

1. Bloom PA, Laidlaw A, Easty DL. Spontaneous development of retinal ischaemia and rubeosis with retinal racemose angioma. Br J Ophthalmol. 1993;77(2):124-125.

2. Rundles WZ, Falls HF. Congenital arteriovenous (racemose) aneurysm of the retina: report of 3 cases. Arch Ophthalmol. 1951;46(4):408-418

3. Meyer CH. Rodriquez EB, Mennel S, Klinqmuller V, Kroll P. Functional and anatomical investigations in racemose hemangioma. Acta Ophthalmol Scand. 2007;85(7):764-771.

4. Yang C, Liu YL, Dou HL, Lu XR, Qian F, Zhao L. Unilateral hemi-central retinal vein obstruction associated with retinal racemose angioma. Jpn J Ophthalmol. 2009;53(4):435-436.

5. Archer DB, Deutman A, Ernest JT, Krill AE. Arteriovenous communications of the retina. Am J Ophthalmol. 1973;75(2):224-241

6. Traboulsi EI. Neovascular glaucoma and ischemia.J Clin Neuroophthalmol. 1986;6(2): 126 .

7. Mansour AM, Wells CG, Jampol LM, Kalina RE. Ocular complications of arteriovenous malformations of the retina. Arch Ophthalmol. 1989;107(2):232-236.
Clinical Ophthalmology

\section{Publish your work in this journal}

Clinical Ophthalmology is an international, peer-reviewed journal covering all subspecialties within ophthalmology. Key topics include: Optometry; Visual science; Pharmacology and drug therapy in eye diseases; Basic Sciences; Primary and Secondary eye care; Patient Safety and Quality of Care Improvements. This journal is indexed on

\section{Dovepress}

PubMed Central and CAS, and is the official journal of The Society of Clinical Ophthalmology (SCO). The manuscript management system is completely online and includes a very quick and fair peer-review system, which is all easy to use. Visit http://www.dovepress.com/ testimonials.php to read real quotes from published authors. 